\title{
The Politics of Age and Generation at the GAZE International LGBT Film Festival in Dublin
}

\section{Introduction}

The 23rd GAZE International LGBT Film Festival in Dublin took place in 2015 several months after the historic 'Yes' vote in the referendum on the Thirty-Fourth Amendment of the Constitution (Marriage Equality Bill) 2015 which approved same sex marriage equality in the Irish Republic. Same-sex marriage equality was approved by $62 \%$ of voters - the first time in which marriage equality had been secured in a national referendum. In a speech at the opening ceremony of the festival, Aodhan O'Riordain, the then Irish Minister of State for Equality, New Communities and Culture and Labour TD announced a national plan for LGBT issues. The use of the festival as a platform to discuss LGBT law reform and social policy initiatives draws attention to the role of festivals such as GAZE in promoting LGBT human rights struggles. Loist and Zielinski (2012) have argued that such festivals have been embedded within activism since their inception. Furthermore, Schoonover (2015) notes that the growth and global orientation of LGBT film festivals since the 1990s has occurred at the same time as the development of an international human rights discourse around LGBT rights. The timing of the 2015 festival several months after the Marriage Equality vote and in the same month as the passing of the Gender Recognition Bill 2015 meant that it provided an opportunity to celebrate and mark this landmark in the struggle for LGBT rights in Ireland. It also provided an occasion to reflect on how to set this achievement in the context of a longer history of struggles and other legal landmarks such as the decriminalization of male homosexual acts in 1993 - the year after the Dublin Lesbian and Gay Film Festival was founded (before it was later rebranded as GAZE). The 
festival thereby constitutes an important site for the reproduction of memory around these legal landmarks, as well as a site for the production of intergenerational solidarity around these struggles.

In this article, we argue that queer film festivals are key sites for the production of queer sociality, collectivity and memory. Drawing on an empirical qualitative study of the GAZE International LGBT Film Festival in Dublin, which has been conducted as part of a larger comparative research project into queer film festivals (QFF's) in Europe, we show that the rhetoric of community is central to the discourses deployed by organisers. We are in particular interested how questions of age and intergenerationality figure in the reflections of key organisers on the role and purpose of creating and transforming community relations and how this translates in programming decisions. We argue that GAZE creates cinematographic and events-based encounters that shape intergenerational bonds that connect with local and global imaginations of community. QFFs assemble relationships among film exhibitions, audiences, participatory events, historical narrative, affects and desiring bodies to produce queer bonds under the sign of festivality.

The cultural activism of queer film festivals is embedded within networks of power relations and social and material inequalities. These in turn shape the possible forms of queer bonds that are produced within festival spaces. European queer film festivals have been affected by the economic crisis, which has meant that these already precarious cultural institutions have come under further pressure for funding given cutbacks in state support (Loist, 2011; see also Di Feliciantonio and Brown, 2015; Eleftheriadis, 2015 for discussions of the sexual politics of austerity more broadly). The politics of austerity in Ireland provide the context for our understanding of the forms of intergenerational queer 
collectivities and solidarities produced through the festival (see also Carney et al 2014). Our discussion thus focuses on the interconnected frameworks of age, temporality and intergenerationality, and how they shape the queer bonds produced at this festival during the economic crisis.

The article is structured as follows. After a review of the literature on queer film festivals in relation to different ways of thinking about queer bonds of collectivity; a brief discussion of the research project and its methodology; and an introduction to the GAZE International LGBT Film Festival, we examine discourses of community by organisers of the festival in relation to notions of age and generation. We then proceed to discuss the role of the festival in relation to the past and present of LGBT politics in Ireland. The analysis proceeds to examine how programming is used by the festival organisers as a means not only to shape audiences, but also to help creating a sustainable community. We argue that GAZE perceives of itself as a vital force in connecting people around LGBT culture and forming and nurturing queer bonds among them.

\section{Queer Film Festivals, Community and Queer Bonds}

Queer film festivals have long been recognised by film scholars as important sites of contemporary queer collectivity and sociality (Clarke, 1999; Rich, 2006; White, 1999) Yet queer film festivals -like film festivals more generally remain largely understudied within the social sciences (Iordanova and Cheung, 2010). The same observation applies to festivals in general, at least in as much their cultural dimensions are concerned (Giorgi and 
Sassatelli, 2011). Much more has been written about Pride marches compared to the LGBTQ cultural festivals that are often organized in conjunction with them or that take place independently of them (though see Kajinic, 2010; Taylor, 2014).

Loist and Zielinski (2012) have highlighted the significance of the LGBTQ niche festival circuit as specialist events for the enjoyment, circulation, and popularisation of films, which are otherwise difficult to access (Loist 2016). Although there are economic interests and investments at stake in the staging of queer film festivals (Rhyne 2006), for many their organisation is primarily a question of political and cultural activism (Loist and Zielinski, 2012). Loist (2011) characterises queer film festivals as occupying a distinctive niche that are driven by the voluntary efforts of 'dedicated groups' concerned with representational politics and tend to get recognized or receive funding only later.

In a seminal article, Gamson (1996: 238) has examined the organizational politics of collectivity associated with lesbian and gay film festivals in New York City in the 1990s, arguing that: 'film festivals are, one might say, homes or warehouses for collective identity; they involve ongoing and self-conscious decision making about the content and contours of the 'we' being made literally visible'. Gamson (ibid.) goes on to argue that: 'festival organizations are engaged in an ongoing process of identity framing, making visible particular versions of group 'consciousness and character' (Hunt et al., 1994: 203)'. As spaces that proactively contest dominant representations, they have been conceptualised as 'counterpublic institutions' (Clarke 1999: 85), 'counter public sphere' (White 1999: 73) or 'transnational queer public' (ibid: 1999: 78). 
Research on queer film festivals stresses the significance these events have for the creation of a sense of community, both with regard to local LGBTQ communities (Rich, 2006; Bradley, 2006) and their transnational imaginings (Schoonover and Galt, 2016). Community has been a core concept in sexuality studies and the social movements that have formed around marginalised genders and sexualities. Weeks (1995) has highlighted the emphasis the early decades of lesbian and gay politics put upon the formation of a coherent communities. Community formation was also an important aim of the transgender and bisexual movements (Whittle, 2002; Klesse, 2007). For Weeks (2000), community is a 'necessary fiction' that sustains individual and collective identities, functions as repository of values, mobilises social capital that sustains political struggles and modes of sexual citizenship, and is as such indispensible for sexual politics. Community has been theorised in manifold ways with conceptual differences being due to either the context concerned and/or the theoretical framing applied. Historical and sociological studies of gender and sexual dissidence suggest that modernity and urbanisation enabled the establishment of often highly specialised sexual subcultures, with spaces for men reaching a higher degree of institutionalisation (D'Emilio, 1983; Chauncey, 1994; Faderman, 1991). Criminalization and violent oppression effected the creation of carefully guarded and often highly secretive spaces and networks. Scholarship in early decades of the $20^{\text {th }}$ century often referred to these diverse social spaces with terms such as the gay world (Hoffman, 1968; Dank, 1971). Some scholars used the term subculture to refer to these secluded worlds to highlight the friction of these spaces and social networks with the dominant heteronormative order (Blachford, 1981). Plummer (2001) speaks of cultures of dissident desire in order to signify these divergences and the cultural or political dissonances they imply. In more recent times, the concept of sexual fields has guided the study of the dynamics of erotic and sexual interaction in certain locations, 
including subcultural settings (see Green, 2008; Martin and George, 2006) fusing Goffman's socio-psychological interactionism with Bourdieu's more structural work on routine practices to explore the social organization and stratification of the sexual choices actors take in certain contexts and environments.

All these concepts provide interesting avenues from which to explore the formation of communities through social events, such as queer film festivals. However, they also have their shortcomings. The terminology of a 'gay world' (or, alternatively, of gay male, lesbian, bisexual and transgender worlds) suggests a coherence and unification that cannot take account of the manifold differences that separate contemporary LGBTQ populations. The notion of a $L G B T Q$ community, too, has been criticised for downplaying social divisions that result not only from differing cultural identifications, but also from exclusive practices around gender, ethnicity/race, religion, class and disability (Klesse, 2007). The term subculture is charged with strong connotations of oppositionality, which does not capture the social or leisure aspects of many of the events and places evoked in conversations about community. In many countries, community rhetoric quickly lost its political connotations (referring primarily to solidarity within a social movement) to signify a social world of pubs, discos and clubs that is also often dubbed the 'pink economy' (Cant and Hemmings, 1988). Post-subcultural theory call into question the idealistic investment into oppositional purism of subcultural studies and suggests that the concept evokes strong commitment and adherence to identity-mediated cultural orientations that cannot capture the more lose affiliations that sustain contemporary lifestyles (Muggleton and Weinzierl, 2003). The sexual field perspective narrowly focuses on the interactions, value systems and capital exchanges that structure sexual partner choices. Queer film festivals certainly provide a distinctive space for sexual encounters, a subject that has remained under-studied within 
film festival research. However, our research objectives go far beyond this singular issue, which renders sexual field theory a reductionist way of theorising festival sociality in this paper.

All the concepts discussed in this section share a strong emphasis on intersubjective, face-toface interaction. However, community formation draws also on imaginary processes that by far exceed embodied interpersonal encounters (Jones 1997). Sexuality research has further emphasised the significance of digital media and in particularly the internet for subjectivity and community formation among sexual and gender dissidents (O'Riordan and Phillips, 2007). In order to capture such aspects, concepts such as community, sexuality or the 'social' need to be de-centred. The spatiality of queer film festivals is uniquely complex, being comprised of dispersed material locations (cinemas, cafes, bars and clubs) and quasi-virtual spaces (displayed on screens, produced in inter-textual references and diegetic story telling). Technological mediation structures many of these spatialities (Schoonover and Galt, 2016). Moreover, many film festivals are themselves multi-site and/or transnational, because they have a touring schedule, apart from being located within a quasi- mythological representation of the 'festival circuit' (Loist, 2016).

Schoonover and Galt (2016: 6) apply Puar's (2007) concept of queer assemblage to their study of queer cinema whose 'queer worlds [....] are made available through cinema's technologies, institutional practices, and aesthetic forms, which together animate spaces, affective registers, temporalities, pleasures, and instabilities unique to the cinematic sensorium' (ibid.: 6). Assemblage theory helps us to recognise queer film festivals' complex connectivity, which is evidenced in the interplay of multiple elements (organising networks, audiences, films, screenings and exhibitions, events, venues, trailers, programmes, etc.), multiple localities and scales of spatiality (film theatres and festival 
venues, touring programmes and complex relations to queer and mainstream circuits of international film festivals) (Loist, 2014; De Valck et al., 2016).

The concept of 'queer bonds' has been offered as a promising alternative to the out-right refusal by certain currents within queer theorising to engage with the question of sociality after the so-called anti-social turn (Weiner and Young, 2011, Edelman, 2004; Muňoz 2009). The logic of queer bonds avoids the fallacy of idealistic and/or normative ideas of intimacy and community by going beyond merely anthropocentric frames and conceiving of queerness from the perspectives of both its 'world-making and world-shattering' qualities (Weiner and Young, 2011: 224). For some, this allows a critical re-engagement with questions of futurity and a cautious envisioning of 'queer sociality' as an 'utopian space that both performs a critique of existing social relations of difference and enacts a commitment to the creative critical work of imagining collective possibilities' (Rodríguez 2011: 332). Before we examine the queer socialities produced at one queer film festival, we next provide a discussion of the methodology of the empirical project in which this analysis is based.

\section{About the study}

This article draws on empirical data from one research site within a larger comparative study of queer film festivals in Europe that took place between June 2013 and August 2015. The study explored the role of 5 queer film festivals in articulating LGBTQ political agendas in the public sphere in different European geopolitical contexts. The festivals we chose to study were the Queer Sicilia Film Festival in Palermo; the GAZE International LGBT Film Festival in Dublin; the Lesbisch Schwule Filmtage/International Queer Film 
Festival in Hamburg; the Mezipatra Queer Film Festival in Prague and Brno in the Czech Republic, and the Merlinka International Queer Film Festival in Belgrade.

The study focused on the networked and relational spaces of solidarity, affinity and connection that shaped the production of these festivals. It examined programming decisions and promotional activities; and the cultural geopolitics of local, regional, national and international regimes of funding and institutional support for each festival. Furthermore, it included the analysis of the role of these festivals in the formation of LGBTQ communities and queer visibilities. Our methods included participant observation at festival and film exhibition events and interviews with core organisers (programmers, directors, board members and those responsible for fundraising, PR and marketing, hospitality, etc.), volunteers plus a small number of participants in the audience (usually loyal long-term attendees who often assumed volunteering roles in the past and/or international guests). It was a conscious decision to focus only on organisers of these events as we sought to complement rather than replicate other studies of European queer film festivals that focussed on the audience experience of these events (Perriam and Waldron, 2016). Across all sites, we conducted 62 qualitative semi-structured interviews. In total, we undertook 10 interviews with festival organisers at GAZE - including the Director, Programmer, board members and volunteers during 2013 and 2015. The interviews chiefly focussed on the organisation and funding of these festivals; and on the goals, aspirations and reflections of these key participants. None of the participants at GAZE wished to anonymise their contributions, though two participants at another festival site wished to maintain their anonymity. Interviews and field-notes were analysed drawing on an interpretive approach that included frequent listening of interview recordings and thematic coding of the interview transcripts (Gubrium et al. 2014). This was supplemented by discourse analysis of festival programmes, promotional material and participant 
observation at each festival site. The following discussion focuses on one research site, the GAZE International LGBT Film Festival in Dublin.

\section{The GAZE: International LGBT Film Festival, Austerity and LGBTQ Cultural Politics in Ireland}

The GAZE International LGBT Film Festival in Dublin celebrates its $25^{\text {th }}$ anniversary in 2017. It was founded in 1992 as a touring package of 15 feature and documentary films from the London Lesbian and Gay Film Festival. It was previously called the Dublin Lesbian and Gay Film Festival before its rebranding as GAZE (see Schoonover, 2015 for a discussion of the politics of naming and branding queer film festivals). The touring package of the LLGF continued to be an important component of the festival for a number of years, though by the 2000s the festival also included a strand of films from other festivals including the Toronto International Film Festival. GAZE has been transformed over time from a small community event organised without any funding - which exclusively relied upon DIY and grassroots organising to an institutionalised, professionally run festival with a Board of 9 people, plus a paid professional programmer and manager. The festival takes place over the August bank holiday weekend. According to Noel Sutton, the Festival Director, GAZE is: 'the biggest community event outside of Pride so we attract people from all over the country to come for the weekend'. Over the history of the festival, it has taken place at a number of venues in Dublin including the Irish Film Centre. The 2013 festival took place in The Lighthouse Cinema in Smithfield. Funders of the 2015 festival include the Arts Council, Dublin City Council and the Broadcasting Authority of Ireland. Since 2012, the major corporate sponsor of the festival was Accenture the 
multinational management consultancy, which has its corporate headquarters in Dublin. GAZE has a particular remit to support Irish filmmaking and is also a partner of the Iris Prize Shorts Festival. According to Michael Connell, the Chair of the Board of GAZE in 2015, the main purpose of the festival is as follows: 'GAZE is about LGBT visibility, advocacy, and remembrance. The programme invites us to look back honestly, to look around us critically, and to look forward with intent. We are passionate about providing a platform for new and Irish LGBT film and filmmaking, and for facilitating access to LGBT film for those of limited means'. (Film Ireland, GAZE Film Festival 2016). It is this emphasis on the festival as a site of remembrance that we will revisit in our later

In their study of global queer cinema, Schoonover and Galt (2016: 81) argue that: 'the queer film festival not only reflects the world but actively makes and remakes worlds'. Like other queer film festivals, GAZE is therefore a key site in 'queer worlding' (Binnie, 2014, Manalansan IV, 2015). This notion of queer worlding is key to the forging of queer bonds beyond Dublin, both within and beyond Ireland. The festival is part of the global queer film festival circuit and shows films about LGBTQ lives elsewhere as a form of domestication for a Dublin and Irish audience. At the same time, the festival has a mission to promote Irish queer film internationally - through for instance forging links with other festivals to show Irish queer film premiered at GAZE, through its 'GAZE on tour' programme. A package of Irish LGBT films was shown at the Image and Nation queer film festival in Montreal in 2016. GAZE shows Irish short films at Craic Fest at the Irish Arts Center in New York and contributes Irish short films towards the Iris Prize short film festival. For Michael Connell, Chair of the Board of GAZE, the festival has a key remit to educate: 'It's as much about educating the people in Ireland...or about trying to change Ireland as it is about trying to change the rest of the world'. The human rights activist 
dimension of the festival is also emphasised by the Festival Director, Noel Sutton, who argues that LGBT film festivals are necessary because of the prevalence of human rights abuses against LGBT people across the globe:

'But we're also very aware, and that's why a film festival like this is of most importance. We are very aware of the fact that we're quite lucky here in Ireland. That we can walk down the street and hold hands. But that's not the case for everyone else in Europe, and certainly not the case for everybody else in the world. We know that our LGBT brothers [sic] who live in fear of being bashed, imprisoned and even murdered. Until we can reach a stage we have a shared world vision around the world LGBT film festivals and many other festivals, theatre festivals are important and we're going to keep going.'(Noel Sutton, Festival Director, 2015). (our emphasis in italics)

The festival is therefore significant in terms of the connections made between LGBT rights activist struggles in Dublin and the rest of the globe. In the 2015 edition of the festival there was a palpable sense of celebration, achievement and mood of optimism given the yes vote in the marriage equality referendum. The development and growth of GAZE can be set in the both the context of the development of queer film festivals internationally, and the development of queer cultural institutions and festivals during the economic boom years of the Celtic Tiger years in Ireland. Walsh (2016: 7) explicitly mentions GAZE as part of the explosion of queer cultural activity in the 1990s: 'GAZE International LGBT Film Festival has been crucially important in screening queer cinema in Ireland since its establishment in 1992.' Cronin (cited in Mulhall, 2011: 104) has argued that there had been an important shift in the discursive terrain around queer during the Celtic Tiger years, suggesting that: 'the queer has been made to signify modernity and progress, so 
that the legislative gains and increasing toleration of the gay and lesbian community represent Ireland to itself as a 'tolerant, progressive, and modern society' (Cronin, 2004: 251)'. Some statements by study participants reflected this sentiment.

O'Flynn et al. (2014) argue that Ireland has been disproportionately affected by the global economic and Eurozone crisis compared to other EU member states, which the Fine Gael/Labour coalition government responded by implementing an austerity programme which has targeted public sector works and unions. Walsh argues that the global economic recession since 2009 has led to greater politicisation of LGBTQ issues in Ireland. The economic crisis and austerity has affected social relations and cultural politics across Ireland and has had consequences for queer cultural production and events such as GAZE. Declan Buckley -one board member of GAZE frames the turn towards seeking out business sponsorship as a direct consequence of austerity and cuts to state funding of arts and culture in Ireland:

'we obviously in Ireland are having economic difficulties for the last number of years. That created a threat to us because historically a much greater percentage of our funding, of our income was from grant awarding bodies. Those grant awarding bodies obviously get their money from state funds. State funds are nonexistant so therefore there have been massive cuts across the board in all of the arts areas, including the grants that we got ourselves the last couple of years, so shifted our focus to making strategic alliances with businesses, like the relationship that we've got with Accenture (Declan Buckley, Board Member, GAZE) 
The economic crisis constituted a key point of reference by other respondents. For instance, Eibh Collins- the volunteer and quest coordinator of the Festival - stated that it was hard to find volunteers, because of the lack of paid work:

'it's very hard to get people to volunteer. It really is. Like you think a lot of...especially I'm referring to at a moment in Ireland. You think that people take the chance to get out and move out and meet new people, but it's just..it is still very, very hard for people. Everyone thinks they deserve money for their time and that's the real problem with Ireland at this moment and so it's hard to get people who are really interested' (Eibh Collins).

Eibh's repetition of the phrase 'at this moment' indicates acknowledgement of the present as a moment of social and economic crisis. Voluntary work is a form of unpaid labour and only people whose basic needs are met by other forms of income can afford to engage in it. The quote also highlights to what extent GAZE (like other queer film festivals) relies in its operation on the labour of volunteers, which reveals as much about the ethos of queer film festivals as a community event or a form of activism, as about the scope of its budgets, its distinctive style of economic organisation and its implication in structural relations of labour (Loist, 2011).

\section{Age, Temporality and Intergenerationality}

Ken Plummer's (2010:165) landmark essay on age and generation in sexuality studies argues that 'all sexualities dangle from an age perspective. They are situated in age standpoints'. Plummer articulates the notion of 'generational narratives' by which he 
means the common set of experiences that shape the standpoints of different generations. Plummer acknowledges that there are also significant differences within each generation and his argument is sensitive to multiple dimensions of difference. Munoz's (2009) work on queer utopianism articulates a vision of queer as a form of collective sociality produced through difference and a rejection of the limitations of the present. Drawing on both perspectives, we therefore suggest that an age, time and generation perspective can make an important contribution to the analysis of solidarities produced through event spaces of queer film festivals. Rich (2006: 620) identifies 'generational difference within queer communities' as one of the key pressures on LGBTQ film festivals. Furthermore, Rich has argued that queer film festivals are important sites of memory reproduction, as 'destinations to which folks make pilgrimages to fix memory and reclaim history' (2006:624). Following Rich, we suggest that such festivals are significant as sites for the transmission and reproduction of histories. Moreover, these struggles are ongoing and therefore always in the present, rather than simply belonging in the past. Questions of age, temporality and intergenerationality also emerged as key themes in our interviews with organisers and volunteers in the festival. The 'generational narratives' referred to by Plummer (2010) are framed here within national, regional, local and global temporalities. These are the main issues that are the focus of our analysis of the temporal and spatial politics of the GAZE International LGBT Film Festival in the reminder of this section. Our analysis of these issues is structured and organised around three key themes -1) GAZE as a site of intergenerational community: 2) GAZE as a site of remembrance; and 3) Demography and the sustainability of the festival. 


\section{GAZE as a site of intergenerational community and queer bonds}

For the organisers and volunteers we interviewed we found that discussions about the value and importance of the festival were often framed in terms of community. For instance, Noel Sutton the festival director stresses the community basis of GAZE: 'Our film festival, a lot of the film festivals we attend are industry-led, and we're not, we're the opposite, we are community-led' (Noel Sutton, Festival Director, 2015). The communitybasis of GAZE is emphasised later in the same interview: 'We're a community coming together, a group of people coming together....to share our journeys and also you know our struggles....and also you know we are a community as well and we want to share that...and we want to celebrate that' (Noel Sutton, Festival Director, 2015).

A number of our respondents argued that the festival was distinctive as a site of community because it brought together in one space, at one time, people that would not come together or occupy the same space at other times of the year. For instance, Denis Dermody, Chair of the Board of the festival in 2013 notes that:

'I think the women get a lot out of it, particularly because in Dublin there's not many lesbian clubs. I think there's one night a week or may be one night a month where women in their thirties, forties, fifties and sixties can go where the emphasis is not dancing and young people and drugs and so on so I think they get a lot out of it here so I think that's significant.'

In this quote, we can see a strong reference to age in relation to the distinctive character and nature of the festival. It is a rare social space where older lesbians (and bisexual 
women) can come together and experience a sense of community. Other respondents also commented on the age demographic as a unique feature of the festival that make it distinctive. For instance one volunteer, when asked about the most rewarding aspect of being a volunteer, states that:

'you kind of very much see the kind of differences between different groups within the LGBT spectrum. It's kind of interesting, especially as a young gay man, I wouldn't find myself ... usually come into contact with trans people or maybe bisexual people. It's interesting to see their views of interact in that kind of way' (Garry, volunteer).

Garry suggests that his age can be an explanation for his lack of experience of the diverse range of queer experiences, which he has yet to encounter in other social spaces, but finds present within the space of the Festival. For Garry, the festival is potential bridging experience, crossing divisions between age, gender identity or sexual identity and practice.

\section{GAZE as site of queer remembrance (and futurity)}

Panel discussions and post-screening $\mathrm{Q}$ and $\mathrm{A}$ discussions provided a platform for the interrogation of the conditions under which successive generations of activists organised their political and cultural interventions, including the festival itself. Major legal landmarks in Irish LGBT politics are key to the framing of generational narratives at the festival. For instance, 2013 marked the $20^{\text {th }}$ anniversary of the decriminalisation of male homosexuality in Ireland, and was a key reference point in the festival brochure and discussions of 
programming. To mark this anniversary, the 2013 festival contained a screening of The Love That Dare Not Speaks Its Name (Dir. Bill Hughes, 2000) which was the first ever documentary on Irish gay life, first broadcast by the national broadcaster RTE in 2000 . The screening was followed by a panel discussion which included the producer and key participants in the film such as the distinguished activist academic Ailbhe Smyth. Bill Hughes received much praise for his film, which marked a watershed in terms of lesbian and gay representation on Irish TV. The discussion was very emotional and in particular people who had lived through the period of criminalization and rigid cultural homophobia stressed the significance of early activism. According to Noel, Director of the Festival, it was a conscious decision to show this film in the 2013 festival, as the organisers were aware that the 2015 Marriage Equality Referendum was in the pipeline:

'that's why we showed that film that year as well because we were still mindful of the lead up to the referendum. We knew we were entering into this phase. We knew the referendum was on the cards. So that's why we've used this festival as well as a toolan educational tool for people to be able to highlight these issues. And to use the festival to bring people on a journey...and we certainly have over the past number of years brought people on that journey...brought people on that journey of not just remembering what went on in the past, but focusing on where we want to be, and focusing on what's going on the future..' (our emphasis in italics).

Noel explains that campaigners for a YES in the quality marriage campaign sought to keep party politicians at a distance, arguing that the focus on story-telling was key to the referendum campaign, and that the film festival was a powerful medium for the communication and sharing of stories: 'that was another really major success and coup for 
us aswell that we were able to keep it about the power of stories, the power of telling our story, and that's what a film festival does aswell - its shares stories, it brings our stories on to the big screen'.

For Noel, the festival plays a key pedagogic role in educating audiences about the history of LGBT rights in Ireland. The programming of The Love That Dares Not Speak Its Name therefore is a conscious decision to help build up consciousness around marriage equality and to forge queer bonds around this issue in the lead up to the marriage equality referendum. The audience at the post-film discussion of this film was mixed in terms of age - including a small number of people in their 20 s and 30 s. This allowed a crossgenerational dialogue to take place, which included questions from younger participants about how to properly recognise the contributions of older generations. During the ensuing debate on activism and the preparation of the campaign on the equal marriage referendum, few participants displayed an un-broken optimism. Some highlighted that it is difficult to discuss homosexuality in public and caution that it was not possible to take law reform for granted.

The intergenerational aspect of crossing group boundaries is particularly well captured by the Irish Short 'Our Love is History' (Dir. Caroline Campbell, 2013), which was a particularly moving example of intergenerational queer bonding; through the intergenerational transmission, restaging and reproduction of Irish queer oral history. It featured transcripts from oral histories of queer spaces in Dublin such as The Hirschfeld Centre, and cruising areas within the city that were read by younger Dubliners. The fact that young people gave voice to the written memories of LGB people of an older generation in an embodied performance as part of a collective act and endeavour 
rendered it such a powerful and moving film. The film was nominated for a GALAS Irish LGBT award in the Irish TV and film category. The scarcity of LGBT or queer themed Irish films due to the uneven political economies of film production - the role of shorts and the festivals promotion of Irish short films is all the more important.

Audience demographics, programming and the sustainability of the festival

One dominant finding from our interviews with festival organisers in 2013 and 2015; was the focus on trying to enhance the sustainability of the festival by consciously appealing to a wider youth audience. There was a perception that the festival had come to be dominated by middle-aged people; and that there was a need to bring in a younger audience through a raft of measures targeting them in order to ensure the long term sustainability of the festival.

We survey every year. We still know that over $50 \%$ of our audience who come here are over 45 years of age. We still have a very good mix between men and women. It works out at about 51 men, 49 women. And the vast majority would be over 50s. And we kind of looked at that in the first few years and we were kind of looking to see how we could appeal to a younger audience...' (Noel Sutton, Festival Director, Gaze)

'I didn't realise that until even last night when everyone here was over 30, there was really no one younger and it just makes no sense when there's topics that either affect them. [..] [The Festival] is massive obviously with the elder gay 
community which is only half the target audience so I noticed here they were hoping to reach more of the younger side' (Eibh, volunteer co-ordinator).

There are a number of obstacles that stand in the way of addressing the lack of younger people in the audience. For example, Michael Connell talked about the tendency among young people to which he referred to as the 'millennial audience' to frequent leisure, party and art events that are not distinctively marked as 'LGBT'. Moreover, the forging of intergenerational solidarities at queer film festivals is often constrained or hampered by structural constraints such as age restrictions associated with film classification, and the licensing of cinemas. Taylor (2014) has argued that the ability of young people to take part in LGBTIQ Pride events and other queer spaces is severely constrained by a number of factors including legal barriers to the entry of under 18 year olds to festival spaces. For our respondents, the main issues in attracting younger people where in relation to programming and the licensing of films for the younger audience. Michael Connell discussed these issues, when describing the process the organisers went through to obtain permission to screen the film Participants (Dir. Paul Rowley, 2015) that featured a cast of children.

The difficulty with that is that we found that not a lot of LGBT features were geared towards younger people firstly, and secondly we had to make sure that because we are a film festival and they have all club certificates. All films have club certificates, so we are very wary about the content that's in them because we can't have anybody under 18 come to the festival unless we get the film. We had to get the film certified by the censorship office - The Film Education Office. So for example Participants - that film that we premiered this year, in order to be able to get the 
cast and crew who are mostly children...the cast are all children to come, we had to get that certified we had to bend over backwards for that (Michael Connell, Chair of the Board of GAZE).

Despite the challenges in attracting the younger audience, Noel noted that there had been a significant widening of the demographic of the festival and that more young people were attending in 2015 compared to previous years, For Noel, the targeting of the younger audience was reflected in the programming choices of the festival - to find films that attracted them to the festival:

'to attract the younger audience you have to make sure you have the film for them aswell..so that's very much reflected in our programme. [...] We've changed. We still cater you know for the older men and older women, but now we have slots that we can specifically target towards young people aswell. (Noel Sutton, Director, GAZE)

One further dimension of strategic programming (Richards, 2016) mentioned by Connell is the use of 'Yestergaze' - a stream of films about Irish LGBT history as a means of attracting younger people as well as those who may have come out later in life:

For the last few years we have programmed three screenings in order to try and bring a youth audience in. Three screenings of that Yestergaze strand where we will focus on just Irish stories on film. That's the way we would localise it because it would tend to be Irish stories on film rather than international stories. So for example we would use that as a strand to get young people in and yet young people clued. (Michael Connell, Chair of the Board). 
This suggests that Irish film was seen as the key to attracting the younger audience. In this context, it is significant that the screenings featuring Irish films tended to bring a wider diversity of age and gender groups together, compared to the distinct gendered division of audiences in other screens, as one volunteer Arianne a self-identified straight ally notes:

'What I noticed though today is the Irish shorts that run half six, that got a huge crowd as well. That got a nice mix. That was the first time I saw a huge mix of women, men, probably straight, gays, lesbians; different ages as well [...] You can say that that was probably the first time I saw that, yes, the film is making everybody come together, which was really nice.' (Arianne, volunteer).

For Arianne, the facilitation of intergenerational audiences is a major achievement within an overarching commitment to creating mixed audiences and a sense of community that transcends differences. The delicate balancing act in terms of developing the younger audience through programming, while maintaining the appeal of the older demographic was apparent in an interview with Roisin Geraghty, the programmer for the 2015 edition of the festival:

'A lot of the diehards of the audience are older so I really feel like they should be catered for and I think they like to see both. I think they still enjoy coming of age stories but I think a few people said to me that it was nice to see something that they could relate to more on the screen because it's so rare that that happens' (Roisin Geraghty, programmer 2015). 
Roisin is therefore cautious about not overlooking or neglecting the older audience, those she describes as 'the stalwarts' of the festival. It is important that their viewing needs are looked after as well as the younger audience. While most interviewees agreed that that the festival has been successful in growing the youth audience, many cautioned that the drifting away of the 'millennial audience' may cause problems in the long run. In order to promote the sustainability of the festival they also suggested that they need to make the festival appealing to audiences beyond the LGBTQ community who could be attracted by the quality of the festival programme.

\section{Conclusion}

In this article, we have argued that GAZE like other LGBT and queer film festivals are important sites for the production of queer bonds, thereby supporting the insights of scholars such as Rich (2006). As the discussion of the Marriage Equality debate demonstrates, GAZE is a significant site of queer worlding; and an important platform for the furthering of LGBT rights struggles both within and beyond Ireland. As we have shown, queer film festivals such as GAZE are also key event spaces for the reproduction of queer collective memory around these struggles. Moreover, we have argued that age, temporality and intergenerationality are key factors in shaping how our respondents discussed their participation in the Dublin GAZE international LGBT Film Festival. Age standpoints were significant in how our respondents framed their experience of the Festival. First, in terms of audience demographics and the sustainability of the festival, festival organisers recognised the need to reach out to a younger audience and actively engage them, though there were structural limits to this with regard to age restrictions in 
terms of licensing laws. Second, the festival provides an important space for intergenerational solidarity and for the intergenerational transmission, reproduction and restaging of oral history. Third, as an international festival, GAZE forms part of a queer transnational public sphere, however it was very much the Irish short films and documentaries and their associated panel discussions where the discussions and audience reactions were most intense. These were also identified by some of our interviewees as sessions where audiences and discussions were most mixed in terms of age and gender; thereby reproducing intergenerational queer bonds. This suggests the on-going importance of national identity as a dimension of queer bonding within LGBTQ cultural activism and politics.

\section{References}

Binnie, J. (2014) 'Relational comparison, queer urbanism and worlding cities,' Geography Compass, 8(8): 590-599.

Blachford, G., (1981) 'Male Dominance and the Gay World' in K. Plummer (ed.) The Making of the Modern Homosexual, London: Hutchinson: 184-210.

Bradley, M., (2006), 'Choosing the ghetto', GLQ: A Journal of Lesbian and Gay Studies, 14(1): $130-132$.

Cant, B. and Hemmings, S., (1988) 'Introduction'. In: B. Cant and S. Hemmings (eds.) Radical Records. Thirty Years of Lesbian and Gay History. London: Routledge: 1-14. Carney, G., Scharf, T., Timonen, V. and Conlon, C., (2014), '"Blessed are the young, for their shall inherit the national debt': Solidarity between generations in the Irish crisis, Critical Social Policy, 34(3): 312-332. 
Chauncey, G., (1994), Gay New York: Gender, Urban Culture, and the Making of the Gay Male World, 1890-1940. New York: Basic Books

Clarke, E.O., (1999), 'Queer publicity- a dossier on lesbian and gay film festivals. Queer publicity at the limits of inclusion', GLQ: A Journal of Lesbian and Gay Studies, 5(1): 8489.

Cronin, M.G., (2004), '"He's my country?: Liberalism, nationalism, and sexuality in contemporary gay fiction', Eire-Ireland, 39(3-4):250-267.

D'Emilio, J., (1983), 'Capitalism and Gay Identity'. In: A. Snitow, C. Stansell, S. Thompson (eds.) Desire. The Politics of Sexuality. London: Virago Press: 140-154

Dank, B., (1971), 'Coming Out in the Gay World', Psychiatry No. 34, (May 1971), 60-77

De Valck, M, Kredell, B and Loist, S., (eds.), (2016) Film Festivals. History, Theory, Method, Practice. London: Routledge.

Di Feliciantano, C. and Brown, G., (2015), 'Introduction: the sexual politics of austerity', ACME, 14(4): 965-974.

Edelman L., (2004), No Future. Queer Theory and the Death Drive. Durham NC. and London: Duke University Press.

Eleftheriadis, K., (2015), 'Queer responses to austerity: insights from the Greece of crisis', ACME, 14(4): 1032-1057.

Faderman, L., (1991), Odd Girls and Twilight Lovers. Harmondsworth: Penguin.

Gamson, J., (1996), 'The organizational shaping of collective identity: the case of lesbian and gay film festivals in New York,' Sociological Forum, 11(2):231-261.

Giorgi, L. and Sassatelli, M., (2011), 'Introduction', Giorgi, L., Sassatelli, M. and Delanty, G. (eds), Festivals and the Cultural Public Sphere, 1-11, London: Routledge. 
Green, A., (2008), 'The Social Organization of Desire: The Sexual Fields Approach', Sociological Theory, 26(1) (2008): 25-50

Gubrium, J. F., Holstein, J. A., Marvasti, A. B. and McKinney K. D., (2014), The SAGE handbook of interview research: the complexity of the craft. Thousand Oaks: Sage. Hoffman, M., (1968), Gay World, New York: Basic.

Hunt, S., Benford, R. and Snow, D., (1994) 'identity fields: framing processes and the social construction of movement identities.' In Larafia, E., Johnston, H. and Gusfield, J.R. (eds.) New Social Movements: From Ideology to Identity, 185-208, Philadelphia, PA.: Temple University Press.

Iordanova, D. and Cheung, R., (2010), 'Introduction', in Iordanova, D. and Cheung, R. (eds.) Film Festival Yearbook 2: Film Festivals and Imagined Communities, 1-10, St. Andrews: St. Andrews University Press.

Jones, S. G., (ed.) (1997), Virtual Culture. Identity \& Communication in Cybersociety. London: Sage.

Kajinic, S. (2010), "Battle for Sarajevo" as "metropolis": Closure of the first Queer Sarajevo Festival according to liberal press', Anthropology of East Europe Review, 28(1): $62-82$.

Klesse, C., (2007), The Spectre of Promiscuity. Gay Male and Bisexual Non-Monogamies and Polyamories, Aldershot, UK: Ashgate.

Loist, S., (2011), 'Precarious cultural work: about the organization of (queer) film festivals,' Screen, 52(2): 268-273.

Loist, S. (2014), Queer Film Culture: Performative Aspects of LGBT/Q Film Festivals. (Phd Thesis), Hamburg: Universität Hamburg, Institut für Medien und Kommunikation. URL: 
http://ediss.sub.uni-hamburg.de/volltexte/2015/7333/pdf/Dissertation.pdf (last accessed: 31 August 2016)

Loist, S., (2016), 'The Film Festival Circuit: Networks, Hierarchies, and Circulation', in M. De Valck, B. Kredell and S. Loist (eds.), Film Festivals. History, Theory, Method, Practice. London: Routledge: 49-64.

Loist, S. and Zielinski, G. (2012), 'On the development of queer film festivals and their media activism', in Iordanova, D. and Torchin, L. (eds.) Film Festivals and Activism, St.Andrews: St.Andrews Film Studies, pp. 49-62.

Manalansan IV, M.F., (2015) 'Queer worldings: the messy art of being global in Manila and New York', Antipode, 47(3):566-579.

Martin, J. L. and George, M., (2006), 'Theories of Sexual Stratification: Towards and Analytics of the Sexual Filed and a Theory of Sexual Capital', Sociological Theory, 24(2) (2006): 107-132.

Muggleton, D. and Weinzierl, R., (eds.) (2003), The Postcultures Reader, Oxford: Berg Mulhall, A., (2011), 'Queer in Ireland: 'Deviant' filiation and the (un)holy family', in Downing, L. and Gillett, R. (eds.), Queer in Europe: Contemporary Case Studies, Farnham: Ashgate, pp. 99-112.

Muñoz, J. E., (2009), Cruising Utopia. The Then and There of Queer Futurity. New York: New York University Press.

O'Flynn, M., Monaghan, L. and Power, M. J., (2014), 'Scapegoating during the time of crisis: a critique of post-Celtic Tiger Ireland,' Sociology, 48(5): 921-937. 
O'Riordan, K. and Phillips, D. J., (eds.) (2007), Queer Online: Media Technology \& Sexuality. New York: Peter Lang.

Perriam, C. and Waldron, D., (2016) French and Spanish Queer Film: Audiences,

Communities, and Cultural Exchange. Edinburgh: Edinburgh University Press.

Plummer, K., (2001), 'Gay Cultures / Straight Borders', in D. Morley and K. Robbins (eds) British Cultural Studies, Oxford : Oxford University Press: 387-398.

Plummer, K., (2010), 'Generational sexualities, subterranean traditions, and the hauntings of the sexual world: some preliminary remarks', Symbolic Interaction, 33(2)163-190.

Puar, J., (2007), Terrorist Assemblages. Homonationalism in Queer Times. London \& Durham: Duke University Press.

Rhyne, R., (2006), 'The global economy of gay and lesbian film festivals', GLQ: A Journal of Lesbian and Gay Studies, 12(4): 617-619.

Rich, B.R. (2006), 'The new homosexual film festivals', GLQ: A Journal of Lesbian and gay Studies, 12(4): 620-623.

Rodríguez, J., (2011), 'Queer Bonds', GLQ: A Journal of Lesbian and Gay Studies, 17(2/3): 331-348.

Schoonover, K. (2015), 'Queer or human? LGBT film festivals, human rights and global film culture, Screen, 56(1): 121-132.

Schoonover, K and Galt, R. (2016), Queer Cinema in The World. Durham,NC.: Duke University Press.

Taylor, J., (2014), 'Queerious youth: An empirical study of queer youth cultural festival and its participants', Journal of Sociology, 50(3): 283-298. 
Walsh, F., (2014), 'Pride, politics and the right to perform', in N. Giffney and M. Shildrick (eds.), Theory on the Edge: Irish Studies and the Politics of Sexual Difference,

Basingstoke: Palgrave-Macmillan, 105-122.

Weeks, J., (1995), Invented Moralities. Sexual Values in an Age of Uncertainty, Oxford: Polity Press.

Weeks, J., (2000), Making Sexual History. Cambridge: Polity.

Weiner, J. and Young, D., (2011), 'Queer Bonds', GLQ: A Journal of Lesbian and Gay Studies, 17(2/3): 223-241.

Whittle, S., (2002), Respect and Equality. Transsexual and Transgender Rights. London: Cavendish Publishing.

White, P., (1999), 'Queer publicity- a dossier on lesbian and gay film festivals.

Introduction: On exhibitionism', GLQ: A Journal of Lesbian and Gay Studies, 5(1): 73-78. 